\title{
Improving Mineral Status, Productivity and Fruit Quality of Guava Trees (Presidium guajava L.) Using some Organic Manure Extracts as a Foliar Application
}

\author{
Alaa M. Gomaa \\ Department of Horticulture, Fac. of Agriculture, Suez Canal University, Ismailia, Egypt
}

Received: $10 / 12 / 2020$

\begin{abstract}
In order to study the response of productivity and fruit quality of guava trees to three foliar applications of three organic manures extracts namely: Farmyard, plant compost and chicken manure. A field trial was carried out during two seasons (2019 and 2020) on ten years old guava trees grown in sandy calcareous soil located at CairoAlexandria desert road (70 km from Cairo city, Egypt). The trees received three sprays from these organic manures extracts at start of vegetative growth (first of March), just fruit setting (first of April) and one month later. The obtained data showed that, spraying the three organic manures extracts, individually or in combination, significantly enhanced leaves mineral contents $(\mathrm{N}, \mathrm{P}, \mathrm{K}$ and $\mathrm{Mg})$ rather than untreated trees. Whereas, only the three organic manure extract mixtures (chicken manure (Ch.ME) + compost manure (CME) + farmyard (FME)) significantly increased Ca \% in leaves, during the second season. Remarkable and significant increase was observed for yield (kg/tree) and its components (fruit number/tree and average fruit weight) as a result of spraying the three organic manure extracts individually or in combination compared to untreated trees. Spraying the three organic manure extracts (Ch.ME, CME and FME) significantly improved all physical properties of fruit in terms fruit height $(\mathrm{cm})$, fruit diameter (cm), and pulp thickness $(\mathrm{cm})$, as well as fruit chemical properties in terms of TSS \%, total sugars \% and vitamin C (mg/100 g F.W.) and decreased total acidity $\%$. The best results with regard to yield/tree, fruit physical and chemical properties of guava trees were obtained when the trees were treated three times with the mixture of the three organic manure extracts in combinations (Ch.ME + CME + FME).
\end{abstract}

Keywords: Psidium guajava, calcareous soil, chicken manure, compost manure, farmyard manure

\section{INTRODUCTION}

Guava (Psidium guajava L.) considered one of the most important fruit crops throughout the tropical and subtropical zones. In Egypt, guava is a popular fruit, because of low price and rich source of vitamins and minerals. Under new reclamation desert, guava is one of the leading fruit trees due to its high adaptability and thrives in these soils (Ibrahim et al., 2010). Increasing the percentage of lime in the soil leads to increase soil $\mathrm{pH}$ and fixe many nutrient elements, which negatively affects the trees productivity and fruit quality.

Organic manures fertilizers have an announced role in improving yield and fruit quality of fruits. This is attributed to the increase on the release of most nutrients due to this change from solid to liquid form. Using organic manures achieves many important functions when applied to the fruit crops at the optimum time and concentration. This is attributed to its high content of all nutrients, as well as the higher availability of these nutrients (Marschner, 1995; Mahfouz, 2011; Ahmed et al., 2014; Ibrahim et al., 2015).

The present investigation aimed to study the effect of three organic manure extracts namely; chicken (Ch.M), plant compost (CM) and farmyard (FMT) manure extracts as a foliar application on nutritional status, yield (kg/tree) and its components, as well as fruit physical and chemical properties of Balady guava trees grown in new reclamation sandy calcareous soil.

\section{MATERIALS AND METHODS}

This investigation was carried out during 2019 and 2020 seasons on twenty four uniform 10 years old guava trees. The selected trees were grown in a private orchard located at Cairo-Alexandria desert road (70 $\mathrm{km}$ from Cairo city, Egypt), where the soil texture was sandy loam (Table 1). The planting space was $5 \times 5 \mathrm{~m}$ and drip irrigation system was followed. The selected trees were pruned in the middle of January during the two experimental seasons. The experiment included eight treatments of the three organic manures extracts and its combination, as followed: (1) control treatment, trees sprayed with water; (2)spraying chicken manure (Ch.ME) at 10\%; (3) spraying compost manure (CME) at $10 \%$; (4) spraying farmyard (FM) at $10 \%$; (5) spraying Ch.ME at $10 \%+\mathrm{CME}$ at $10 \%$; (6) spraying Ch.ME at $10 \%+$ FME at $10 \%$; (7) spraying CME at $10 \%+$ FME at $10 \%$; (8) spraying the mixture of Ch.ME + CME + FME. The three organic manures and their combinations were sprayed three times during each season on growth starting at ( $1^{\text {st }}$ week of March), just after fruit setting ( $1^{\text {st }}$ week of April) and one month later $\left(1^{\text {st }}\right.$ week of May). Triton B as wetting agent at $0.05 \%$ was mixed with all organic manure solutions, as well as control solution, before application; spraying was carried out till runoff. The chosen trees under this study were subjected to regular horticulture practices that were commonly applied in the orchard including irrigation, fertilization and pest control.

\section{Soil and water analysis:}

Samples of soil and irrigation water were collected and subjected to physical and chemical analysis according to the procedures of Wilde et al. (1985), Walsh and Beaton (1986) the data are shown in Table (1). 
Table (1): Physical and chemical analysis of experiment orchard soil and irrigation water

\begin{tabular}{|c|c|c|c|}
\hline \multicolumn{2}{|c|}{ Soil analysis } & \multicolumn{2}{|c|}{ Water analysis } \\
\hline Constituents & Values & Constituents & Values \\
\hline Sand $\%$ & 68,1 & E.C $\left(\right.$ ds. $\left.\mathrm{m}^{-1}\right)$ & 1.23 \\
\hline Silt \% & 23.4 & Hardness & 16.7 \\
\hline Clay $\%$ & 8.5 & $\mathbf{p H}$ & 7.25 \\
\hline Texture & Sandy Loam & Ca $(m g / L)$ & 38.4 \\
\hline EC (1 : 2.5 extract $)$ d.m ${ }^{-1}$ & 2.1 & $\operatorname{Mg}(\mathrm{mg} / \mathrm{L})$ & 24.3 \\
\hline Organic matter \% & 0.89 & K (mg/L) & 5.07 \\
\hline pH (1 : 2.5 extract $)$ & 8.18 & $\mathrm{Na}(\mathrm{mg} / \mathrm{L})$ & 95.8 \\
\hline Active lime \% & $12 \%\left(\mathrm{CaCO}_{3}\right)$ & Sum of Cations (mg/L) & 8.16 \\
\hline N (mg/kg) & 199 & Alkalinity (mg/L) & 182 \\
\hline Phosphorus (ppm) & $10.80 \mathrm{ppm}$ & Chlorides (mg/L) & 121 \\
\hline Available Ca (meq/100g) & 17.9 & Nitrate (mg/L) & 11.0 \\
\hline Available Mg (meq/100g) & 3.33 & Sulphates (mg/L) & 53.1 \\
\hline Available K (meq/100g) & 0.56 & Sum of anions $(\mathrm{mg} / \mathrm{L})$ & 7.69 \\
\hline
\end{tabular}

Experimental design and data analysis:

The experiment of design a randomized complete block design (RCBD) and the statistical analyses were performed with SPSS program (SPSS Inc., Chicago, USA). Each treatment was replicated three times; means of the treatments were compared using New LSD test $(\mathrm{P}<0.05)$ (Snedecor and Cochran, 1980).

\section{Preparation of organic manures extract:}

Fresh chicken, plant compost and farmyard manure were obtained from trusted poultry and animal farms in Ismailia City, where the animals or chicken were not fed with hormones or manufactured diets for poultry feed. The manures was placed in burlap bags $(2$ $\mathrm{kg} / \mathrm{bag}$ ), then the bags was placed in plastic drums filled with water (20 liters/drum), a rock was added to each bag of manure to make sure it did not float.150 $\mathrm{g}$ of molase $+10 \mathrm{~g}$ of magnesium sulphate/drum were added. Then, the drums were covered with plastic wraps to complete the fermentation process. After three weeks of fermentation, the organic manures extract were ready to be used.

Table (2): Chemical properties of chemical composition of chicken manure tea, plant compost and farmyard (1:10 extraction) manure extracts

\begin{tabular}{lccc}
\hline Parameters & Ch.ME & CME & FME \\
\hline pH & 7.56 & 7.61 & 7.61 \\
EC (ds.m ${ }^{-1}$ ) & 1.34 & 1.40 & 1.45 \\
Total N (ppm) & 1263 & 989 & 479 \\
Phosphorus (ppm) & 1375 & 979 & 987 \\
Potassium (ppm) & 1987 & 1887 & 1089 \\
Mg (ppm) & 620 & 606 & 592 \\
Ca (ppm) & 291 & 222 & 183 \\
Fe (ppm) & 7.52 & 6.88 & 5.90 \\
Cu (ppm) & 3.01 & 3.12 & 2.81 \\
Zn (ppm) & 2.11 & 2.02 & 1.72 \\
Mn (ppm) & 0.09 & 0.07 & 0.07 \\
\hline
\end{tabular}

Ch.ME $=$ chicken, $\mathrm{CME}=$ plant compost and $\mathrm{FME}=$ farmyard 
Measurements: The following determinations were recorded during both experimental seasons.

- Leaf N, P, K, Mg and Ca contents: 16 mature leaves from the meddle part of the non-fruiting shoots from each tree were picked at full blooming stage. The leaves were dehydrated at $80^{\circ} \mathrm{C}$ overnight, ground to fine powder. Nitrogen was determined by kjeldhal method and phosphorus was determined colourmetrically. Leaf $\mathrm{K}, \mathrm{Ca}$ and $\mathrm{Mg}$ contents were determined using atomic absorption spectrophotommetry (Perkin Elmer 280) according to Martin-Préval et al. (1984).

- Fruit weight $(\mathrm{g})$ and number per tree were recorded at harvesting time, and then the average yield ( $\mathrm{kg} /$ tree) was calculated. Two fruits from each side of the tree at harvesting time were taken to determine fruit physical properties, i.e. fruit height $(\mathrm{cm})$, fruit diameter $(\mathrm{cm})$ and flesh thickness $(\mathrm{cm})$; the same fruits were used to determined total soluble solids (TSS \%), total sugars \% and total acidity (TA \%) according to AOAC (2000). LAscorbic acid (vitamin $\mathrm{C}$; $\mathrm{mg} / 100 \mathrm{~g}$ ) fresh weight of fruit pulp was determined by titration with 2-6 Dichlorophenol-Indophenol. Pectin was extracted and determined by precipitation as calcium pectate $(\mathrm{mg} / 100$ g) (Ranganna, 1985).

\section{RESULTS AND DISCUSSION}

Effect of organic manure on leaves mineral contents:

Data presented in Table (3) indicated that in both experimental seasons (2019 and 2020), spraying guava trees with Ch.ME, CME and FME, individually or in combination, significantly increased leaf nitrogen, phosphorus, potassium, and magnesium contents compared to the untreated trees. However, nonsignificant differences were observed in leaves $\mathrm{Ca} \%$, except those of the second seasons where the mixture of the three organic manures gave higher and significant $\mathrm{Ca} \%$ than the control or other treatments. Using any combination of the three organic manures had a superiority effect on leaves NPK and Mg than using any one alone, during the two experimental seasons. The maximum values were recorded on the trees that received the mixture of the three organic manures (Ch.ME + CME + FME). On the other side, the untreated trees produced leaves with the lowest $\mathrm{N}, \mathrm{P}, \mathrm{P}$ and $\mathrm{Mg}$ contents, during the two experimental seasons.

Using organic manures achieved many important functions when sprayed on the fruit trees at the optimum concentration. This may be attributed to the higher content and availability macro and micro nutrients organic manures. Ibrahim et al., (2015) in clay soil under El-Minia Governorate conditions found that leaf macronutrients ( $\mathrm{N} \%, \mathrm{P} \%$, and $\mathrm{K} \%$ ) were significantly enhanced as a results of mango trees cv. Keitte fertilization four times/year with organic manure with or without Royal jelly and seaweed extract.

Table (3): Effect of foliar spray of chicken, compost and farmyard manures extract on leaves mineral contents (\%) of guava, during 2019 and 2020 seasons

\begin{tabular}{lcccccccccc}
\hline \multirow{2}{*}{ Treatments } & \multicolumn{2}{c}{ N \% } & \multicolumn{2}{c}{ P \% } & \multicolumn{2}{c}{ K\% } & \multicolumn{2}{c}{ Ca \% } & \multicolumn{2}{c}{ Mg \% } \\
\cline { 2 - 10 } Control & $\mathbf{2 0 1 9}$ & $\mathbf{2 0 2 0}$ & $\mathbf{2 0 1 9}$ & $\mathbf{2 0 2 0}$ & $\mathbf{2 0 1 9}$ & $\mathbf{2 0 2 0}$ & $\mathbf{2 0 1 9}$ & $\mathbf{2 0 2 0}$ & $\mathbf{2 0 1 9}$ & $\mathbf{2 0 2 0}$ \\
\hline Ch.ME & 1.20 & 1.22 & 0.14 & 0.13 & 1.25 & 1.23 & 1.42 & 1.40 & 0.35 & 0.39 \\
CME & 1.43 & 1.45 & 0.21 & 0.23 & 1.44 & 1.46 & 1.44 & 1.42 & 0.41 & 0.44 \\
FME & 1.41 & 1.44 & 0.20 & 0.21 & 1.43 & 1.43 & 1.45 & 1.44 & 0.47 & 0.49 \\
Ch.ME + CME & 1.35 & 1.37 & 0.19 & 0.21 & 1.39 & 1.41 & 1.42 & 1.43 & 0.42 & 0.42 \\
Ch.ME + FM E & 1.76 & 1.82 & 0.28 & 0.29 & 1.52 & 1.54 & 1.45 & 1.47 & 0.59 & 0.61 \\
CME + FME & 1.73 & 1.80 & 0.24 & 0.26 & 1.49 & 1.53 & 1.44 & 1.46 & 0.52 & 0.54 \\
Ch.ME + CME +FME & 1.69 & 1.77 & 0.26 & 0.26 & 1.41 & 1.44 & 1.42 & 1.47 & 0.52 & 0.55 \\
New LSD & 1.92 & 1.99 & 0.31 & 0.31 & 1.66 & 1.72 & 1.45 & 1.78 & 0.66 & 0.71 \\
\hline
\end{tabular}


Effect of organic manure extract on yield and its components:

As shown in Table (4) in both seasons (2019 and 2020) spraying the three organic manures three times yearly on guava trees significantly increased fruit weight and fruit number/tree and consequently higher yields (kg./tree) were attained as compared to the control trees. The highest values of these measurements were recorded for trees sprayed with the mixture of the three organic manures (Ch.ME + CME + FME) in combination, followed by those received the mixture of Ch.ME + CME.

During fermentation and decomposition of organic fertilizers, some growth regulators are produced, as well as availability of many nutritional elements are increased. In addition to, production of some chelating compounds that save these elements from loss. All these features may be resulted the positive effect on yield and its components which has been observed in guava trees. Results of some previous studies on other evergreen fruit trees may be confirmed the role of organic fertilization in enhancing yield and its components which obtained in this study such as: Baiea and El-Gioushy (2015) on Grand Naine banana cultivated in sandy soil at El-Katatba region, Minofia Egypt, Ibrahim et al. (2015) on Keitte Mango trees grown under El-Minia region environmental conditions, Egypt, Abd El-Hamid and El-Shazly (2019) on Sukkary mango trees grown in sandy soil at North Sinai environmental conditions, Egypt, Meya et al. (2020) on Banana plant cultivated in volcanic soil under North Tanzania.

Table (4): Effect of foliar spray of chicken, compost and farmyard manures on fruits number/tree, average fruit weight (g) and yield (kg/tree) of guava trees, during 2019 and 2020 seasons

\begin{tabular}{|c|c|c|c|c|c|c|}
\hline \multirow{2}{*}{ Treatments } & \multicolumn{2}{|c|}{ No. of Fruits/tree } & \multicolumn{2}{|c|}{ Fruit weight (g) } & \multicolumn{2}{|c|}{ Yield (kg/tree) } \\
\hline & 2019 & 2020 & 2019 & 2020 & 2019 & 2020 \\
\hline Control & 224.3 & 221.1 & 129.2 & 121.3 & 28.97 & 26.82 \\
\hline Ch.ME & 247.5 & 251.5 & 145.5 & 158.3 & 36.10 & 39.81 \\
\hline CME & 239.3 & 243.7 & 132.7 & 133.3 & 31.76 & 32.49 \\
\hline FME & 234.7 & 248.2 & 139.3 & 150.2 & 32.69 & 37.28 \\
\hline Ch.ME + CME & 268.6 & 282.4 & 168.2 & 123.4 & 44.86 & 34.85 \\
\hline Ch.ME + FME & 269.8 & 275.5 & 155.3 & 159.7 & 41.80 & 43.99 \\
\hline CME + FME & 256.3 & 263.3 & 154.3 & 151.2 & 39.55 & 39.81 \\
\hline Ch.ME + CME +FME & 272.4 & 282.5 & 168.5 & 171.3 & 45.98 & 48.39 \\
\hline New LSD 0.05 & 38.4 & 30.1 & 17.4 & 16.5 & 4.10 & 5.12 \\
\hline
\end{tabular}

Effect of organic manure extract on fruit physical and chemical properties:

Data concerning the effect of three sprays of the three examined organic manures on the physical and chemical properties of guava fruits during 2019 and 2020 seasons are presented in Tables (5 and 6). It is clear from these Tables that treating Balady guava trees with the three organic manures tea (Ch.ME, CME and FME) significantly was accompanied with improving fruit height $(\mathrm{cm})$, fruit diameter $(\mathrm{cm})$ fruit pulp thickness $(\mathrm{cm})$, TSS \%, Total sugars \%, Ca-pectat (mg/100g D.W) and vitamin C (mg/100g F.W.) and decreased total acidity $\%$, relative to the untreated trees, during the two experimental seasons. The combined application of the three organic manures (Ch.ME, CME and FME) showed more effectiveness in improving the physical and chemical properties of Balady guava trees followed by spraying Ch.ME and CME. On the onsite side untreated trees produced fruits with lowest fruit physical and chemical properties, during the two experimental seasons.
At is well known that organic manure fermentation and decomposition produced and liberties some growth regulators and nutritional elements, such as IAA, cytokines, N, K, B and $\mathrm{Zn}$. In addition organic manure decomposition producing some chelating compounds that can save the elements from loss (Mengel, 1985; Marschner, 1995; Mengel, 2007; Ibrahim et al., 2015; Meya et al., 2020). The aforementioned roles of organic manure tea could be explanted its effect on improve fruit physical and chemical properties that clearly showed in the present study. Similar results were found by other authors under Egyptian conditions such as, Omar et al. (2012) on Washington Navel orange under clay loam soil at Jafre El-Sheikh region conditions; Baiea and El-Gioushy (2015) on Grand Naine banana cultivated in sandy soil at El-Katatba region; Ibrahim et al. (2015) in Keitte Mango trees grown under El-Minia region environmental conditions, and Abd El-Hamid and ElShazly (2019) on Sukkary mango trees grown in sandy soil at North Sinai conditions. Similar findings were obtained in volcanic soil at Tanzania by Meya et al. (2020) on Banana plant. 
Table (5): Effect of foliar spray of chicken, compost and farmyard manure extracts on fruit physical of guava fruits, during 2019 and 2020 seasons

\begin{tabular}{|c|c|c|c|c|c|c|}
\hline \multirow{2}{*}{ Treatments } & \multicolumn{2}{|c|}{ Fruits height (cm) } & \multicolumn{2}{|c|}{ Fruit diameter (cm) } & \multicolumn{2}{|c|}{ Pulp thickness $(\mathrm{cm})$} \\
\hline & 2019 & 2020 & 2019 & 2020 & 2019 & 2020 \\
\hline Control & 7.25 & 7.19 & 5.79 & 5.82 & 1.23 & 1.21 \\
\hline Ch.MT & 7.78 & 7.89 & 5.98 & 6.12 & 1.39 & 1.42 \\
\hline CMT & 7.56 & 7.71 & 5.87 & 6.04 & 1.33 & 1.38 \\
\hline FMT & 7.44 & 7.52 & 5.81 & 5.99 & 1.32 & 1.35 \\
\hline Ch.MT + CMT & 7.99 & 8.01 & 6.22 & 6.24 & 1.52 & 1.59 \\
\hline Ch.MT + FMT & 7.87 & 7.91 & 6.12 & 6.15 & 1.44 & 1.51 \\
\hline CMT + FMT & 7.79 & 7.83 & 6.01 & 6.13 & 1.45 & 1.42 \\
\hline Ch.MT + CMT +FMT & 8.02 & 8.14 & 6.38 & 6.59 & 1.64 & 1.69 \\
\hline New LSD 0.05 & 0.19 & 0.21 & 0.09 & 0.11 & 0.11 & 0.11 \\
\hline
\end{tabular}

Table (6): Effect of foliar spray of chicken, compost and farmyard manure extracts on fruit chemical properties of guava fruits, during 2019 and 2020 seasons

\begin{tabular}{lcccccccccc}
\hline \multirow{2}{*}{ Treatments } & \multicolumn{2}{c}{$\begin{array}{c}\text { TSS } \\
\text { \% }\end{array}$} & \multicolumn{2}{c}{$\begin{array}{c}\text { Sugars } \\
\text { \% }\end{array}$} & \multicolumn{2}{c}{$\begin{array}{c}\text { Total acidity } \\
\text { \% }\end{array}$} & \multicolumn{2}{c}{$\begin{array}{c}\text { Vitamine C } \\
\text { (mg/100g F.W) }\end{array}$} & \multicolumn{2}{c}{$\begin{array}{c}\text { Ca pectat } \\
\text { (mg/100g D.W.) }\end{array}$} \\
\cline { 2 - 11 } & $\mathbf{2 0 1 9}$ & $\mathbf{2 0 2 0}$ & $\mathbf{2 0 1 9}$ & $\mathbf{2 0 2 0}$ & $\mathbf{2 0 1 9}$ & $\mathbf{2 0 2 0}$ & $\mathbf{2 0 1 9}$ & $\mathbf{2 0 2 0}$ & $\mathbf{2 0 1 9}$ & $\mathbf{2 0 2 0}$ \\
\hline Control & 8.32 & 8.73 & 6.55 & 6.41 & 1.109 & 1.107 & 78 & 81 & 7.12 & 7.16 \\
Ch.MT & 9.21 & 9.32 & 7.40 & 7.56 & 0.918 & 0.907 & 88 & 89 & 9.0 & 9.8 \\
CMT & 9.11 & 9.20 & 7.19 & 7.43 & 0.938 & 0.921 & 81 & 86 & 8.6 & 8.9 \\
FMT & 9.04 & 9.13 & 7.02 & 7.31 & 0.978 & 0.971 & 83 & 86 & 8.0 & 8.4 \\
Ch.MT + CMT & 9.75 & 9.77 & 7.88 & 7.98 & 0.836 & 0.821 & 95 & 98 & 11.1 & 12.0 \\
Ch.MT + FMT & 9.49 & 9.57 & 7.53 & 7.72 & 0.851 & 0.832 & 91 & 93 & 10.5 & 10.8 \\
CMT + FMT & 9.34 & 9.39 & 7.40 & 7.61 & 0.862 & 0.841 & 89 & 93 & 10.1 & 10.6 \\
Ch.MT + CMT & 9.99 & 10.33 & 8.06 & 8.48 & 0.801 & 0.789 & 99 & 106 & 12.1 & 13.2 \\
+ FMT & 1.8 & 1.7 & 1.2 & 1.1 & 0.022 & 0.041 & 3.5 & 4.3 & 0.6 & 0.5 \\
New LSD & 0.05 & & & & & & & & &
\end{tabular}

\section{CONCLUSION}

In order to improve the nutritional status, productivity and fruit physical and chemical properties of guava trees, based on the obtained results it may be highly recommended to spray the trees three times yearly with the three organic manures namely; chicken (Ch.ME), plant compost (CME) and farmyard manure extracts (FME). This observation was markedly pronounced in the trees sprayed with the mixture of the three organic manures extract (Ch.ME + CME + FME).

\section{REFERENCES}

Abd El-Hamid, S. A. and M. M. El-Shazly (2019). Response of Mango trees to organic and biofertilization in north Sinai. Egyptian J. Desert Res., 69(1): 39-66.

Ahmed, F. F., A. M. SAkl, E. H. El-Mamlouk and H. H. Mohamed (2014). Effect of partial replacement of inorganic $\mathrm{N}$ fertilizer partially by using EM, compost tea and humic acid on fruiting of Sakkoti date palms. Stem Cell, 5(2): 40-51. 
AOAC (2000). Association of Official Agricultural Chemists. Official Methods of Analysis $14^{\text {th }}$ Ed. Pp. 494-510.

Baiea, M. H. M. and S. F. EL-Gioushy (2015). Effect of some different sources of organic fertilizers in presence of bio-fertilizer on growth and yield of banana cv. Grande Naine plants. Middle East J. of Agric., 4(4): 745-753.

Ibrahim, H. I. M., M. M. A. Zaglol and A. M. M. Hammad (2010). Response of Balady guava trees cultivated in sandy calcareous soil to biofertilization with phosphate dissolving bacteria and/or VAM fungi. J. of American Science, 6(9): 399-404.

Ibrahim, H. I. M., A. E. M. Mansour and M. A. Merwad (2015). Impact of Spraying some Organic Manure Tea, Seaweed Extract and Royal Jelly on Fruiting of Keitte Mango Trees. Chem Tech Res, 8(4): 2131-2141.

Mahfouz, M. S. M. (2011). Partial replacement of chemical fertilizers by some organic and biofertilizers in Williams banana plants under Minia region conditions. Ph D. Thesis Fac. of Agric. Minia Univ. Egypt.

Marschner, H. (1995). Mineral nutrition of higher plants. $2^{\text {Ed }}$, Academic Press LD, New York.

Martin-Préval, P., J. Gagnard and P. Gautier (1984). L'analyse végétale dans le contrôle de l'alimentation des plantes tempères et tropicales. Second Edition. pp 810 . Technique \& Documentation - Lavoisier, Paris, France.

Mengel, K. (1985). Dynamics and availability of major nutrients in soil. Advances in soil Sci., Vol.
2, Springer-Verlag New York, Increase, pp 89-91.

Mengel, K. (2007). Organic fertilizers, in: Barker, A. V. and D. J. Pilbeam editors. Hand book of plant nutrition. $2^{\text {nd }}$ Ed. Boca Raton, FL.USA: CRC/Taylor and Francis, pp. 91116.

Meya, A. I., P. A. Ndakidemi, K. M. Mtei, R. Swennen and R. Merckx (2020). Optimizing Soil Fertility Management Strategies to Enhance Banana Production in Volcanic Soils of the Northern Highlands, Tanzania. Agronomy, 10(289): 1-21.

Omar, A. Kh., E. B. Belal and A. A. El-Abd (2012). Effects of foliar application with compost tea and filtrate biogas slurry liquid on yield and fruit quality of Washington Navel orange (Citrus sinenesis Osbeck) trees. J. of Air \& Waste Manag. Assoc., 62(7): 767772.

Ranganna, S. (1985). Manuel of analyses of fruit and vegetable products. Tata McGraw-Hill publishing company limited, New Delhi, iix: pp 632.

Snedecor, G. W. and W. G. Cochran (1980). Statistical Methods, $7^{\text {th }}$ Ed. The Iowa State Univ. Press Ames. pp 80-100.

Walsh, L. M. and J. D. Beaton (1986). Soil testing and plant analysis. $6^{\text {th }}$ edition. Editor, Soil science society of America, Inc. pp 489.

Wilde, S. A., R. B. Corey, J. G. Layer and G. K. Voigt (1985). Soil and plant analysis for tree culture. $3^{\text {rd }}$ Ed, Oxford and New Delhi- India Publishing. Pp: 529-546.

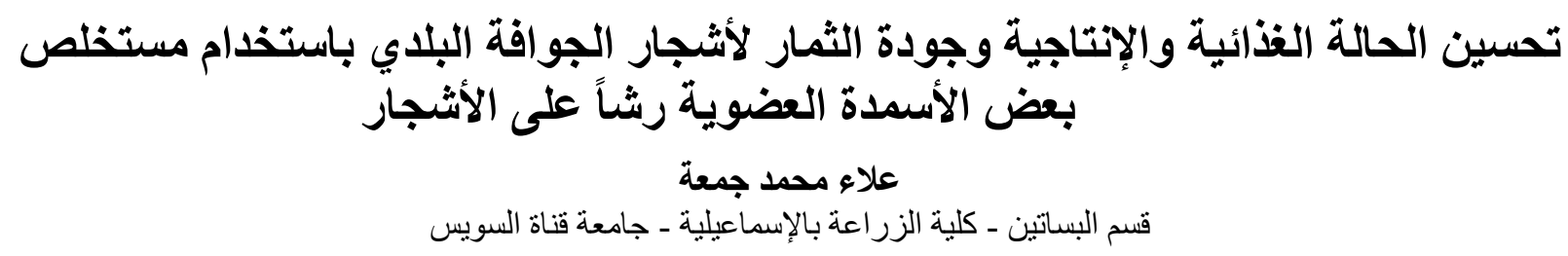

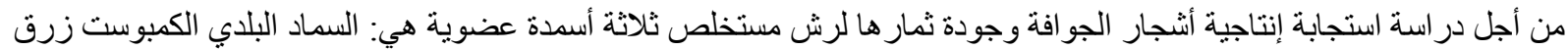

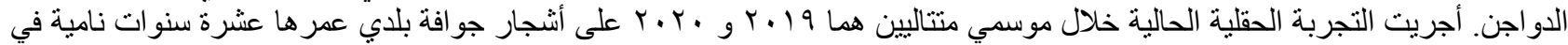

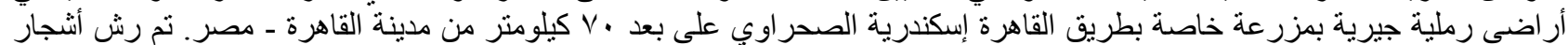

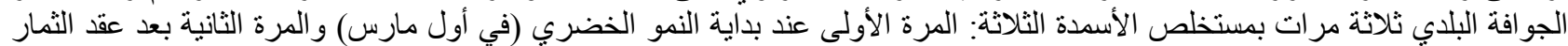

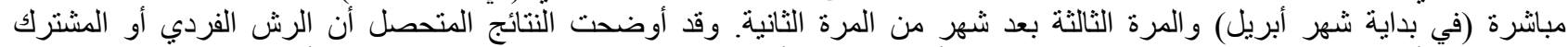

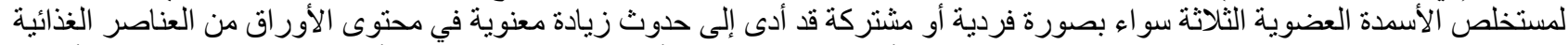

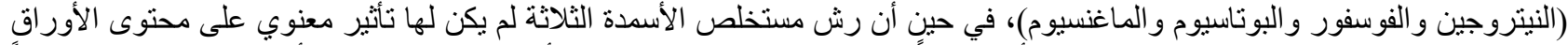

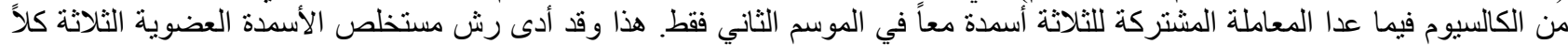

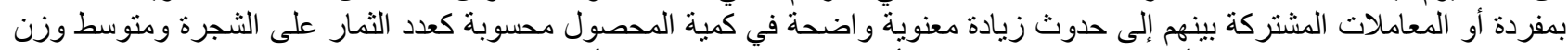

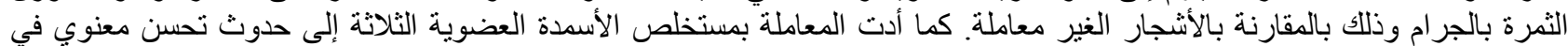

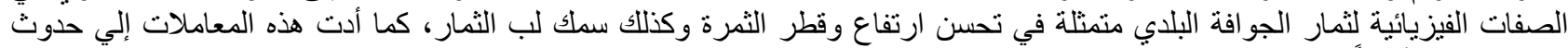

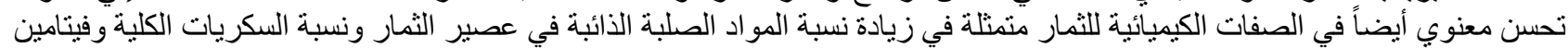

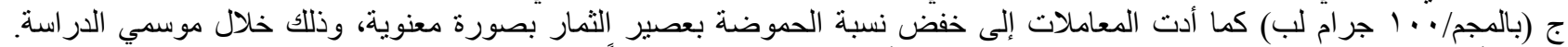

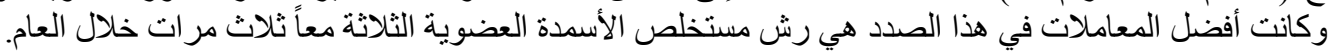

